\title{
Effect of attitudes, subjective norms and behavioral controls on the intention and corrupt behavior in public procurement: Fraud triangle and the planned behavior in management accounting
}

\author{
Zulaikha $^{\mathrm{a}^{*}}$, Paulus T. Basuki Hadiprajitno ${ }^{\mathrm{a}}$, Abdul Rohman ${ }^{\mathrm{a}}$ and Rr. Sri Handayani ${ }^{\mathrm{a}}$
}

aDepartment of Accounting, Diponegoro University, Semarang, Indonesia

\begin{tabular}{l}
\hline C H R O N I C L E \\
\hline Article history: \\
Received: August 29, 2020 \\
Received in revised format: \\
October 302020 \\
Accepted: November 21, 2020 \\
Available online: \\
November 21, 2020 \\
\hline Keywords: \\
Corruptive attitudes \\
Subjective norms \\
Perceived behavior control \\
Intentions to corruption \\
Corruptive behavior
\end{tabular}

\section{Introduction}

Corruption in the administration of public sector both in central and regional government in Indonesia by officials, people's representatives, partners, is a serious problem. Financial management by state officials is still colored by irregularities as stated in the 2015 Anti-Corruption Agency (KPK) report. Transparency International Indonesia/TII (2019) also reveals the vulnerability of corruption in the public sector in Indonesia, by presenting the Indonesian's Corruption Perception Index (CPI). TII (2019) found that Indonesia's CPI in 2019 is at a score of 40/100 and is ranked 85th out of 180 countries surveyed. Umar (2011) reveals that the indication of corruption cases in Indonesia is 70 percent dominated by the procurement of goods and services. Hehamahua (2011) states that from 2004 to 2009 there were a total of 63 cases related to the procurement of goods and services out of 148 corruption cases handled by the Anti-Corruption Agency (KPK). Furthermore, Hehamahua (2011) states that the mode of deviation in the procurement of goods and services at the procurement committee level is weak integrity, nontransparent procurement processes, impartial procurement committees, non-independent procurement committees. According to Indonesian Law Number 31 of 1999, corruption is an act against the law to enrich oneself or other people or a corporation that can harm the State's finances or the country's economy. Corruption provides benefits to those who do it, but harms or brings

* Corresponding author

E-mail address: zulaikha.feundip@gmail.com (Zulaikha)

(C) 2021 by the authors; licensee Growing Science, Canada doi: $10.5267 /$ j.ac.2020.11.020 
the impact of losses where they work or loss of State finances, damage to the reputation of the organization, damage to employee morale and other negative impacts. There are various things that encourage corruption. Cressey (1973) proposed the fraud triangle theory that encourages corrupt behavior because of three things of pressure, opportunity, and rationalization. Some corrupt behavior was just a result from a weak system or an unsupervised environment. Many of them occur because of the individual's psychological drive to view norms and self-control on corrupt, fraudulent behavior.

To examine the extent to which the psychological factors able to affect the intentions and corrupt behavior in public sector, especially in public procurement, this study was conducted by taking the accounting management perspective. Hence, Theory of Planned Behavior from Ajzen (1991) was adopted in this study to analyze why corrupt actions occur. This study aims to analyze how people's attitudes, subjective norms owned by the community and control of community behavior that can form the intention to behave and ultimately corrupt behavior occurs. This research is designed as a field study by conducting a survey of respondents to the public which includes: government officials, suppliers of government goods and services procurement, representatives of the people, accounting educators, government internal auditors, government external auditors, and the general public to explore the value system owned by them and their perceptions of corrupt attitudes and behavior. This corruptive phenomenon is used as the dependent variable and will be analyzed in terms of the factors that influence it, which are developed into factors such as Cohen et al., (2012) used to analyze fraud, namely: attitude toward corrupt, subjective norms, perceived behavioral control. These three variables influence intention to engage in corruption, which in turn affects corrupt behavior. This study explores the values that develop in society which are social constructs that are thought to be related to attitudes, norms, and controlling individual behavior in society and in turn can foster corrupt intentions and behavior.

\section{Literature Review and Hypotheses}

\subsection{Individual Attitude with Intention for Corruption and Corrupt Behavior}

In terms of fraud, Cressey (1953) stated that fraud can occur because it is triggered by 3 factors of pressure, opportunity, and rationalization. This model is known as the fraud triangle theory. The first factor is the presence of pressure, especially financial pressure. This factor is getting attention because a person's income makes it possible to corrupt. Research conducted by Van Rijckeghem \& Weder (1997), Lambsdorff (1999) show that there is a positive effect of inadequate income on the level of corruption. The low income of government officials is considered as one of the conditions that triggers irregularities and corruption (Financial and Development Supervisory Agency/BPKP, 1999). However, the most perpetrators of corruption are government officials, parties with authority, as well as entrepreneurs who are partners in the procurement of government goods and services who pay bribes to authorities. In this context, Telgen et al. (2012) show that there is a relationship between attitude and intentions for corruption in public procurement (Ateljevic \& Budak, 2010). From an economic point of view, they are people who are quite well-established, economically "feasible" to pay for their lives. This attitude of seeing the proper need for life can encourage someone to commit or intend to be corrupt. Based on this description, the hypotheses proposed in this study are as follows:

H1a: Individual's low attitude towards corruption is positively related to intentions for corruption.

H1b: Individual's low attitude towards corruption is positively related to behavior for corruption.

\subsection{Relationship of Subjective Norms with Intention for Corruption and Corrupt Behavior}

There is a relationship between norms and corruption intentions. The study shows that subjective norms can be driven by opportunities. These factors allow a person to commit corruption or misuse of authority which may not be easily detected or detected. Dorminey (2012) states that opportunities can occur if there are weaknesses in supervision, and the perpetrator has the opportunity to commit fraud without being easily detected. It is also stated that this opportunity can occur because of a weak internal control system, ethics and a supportive procurement environment and considers someone who is trusted not to commit fraud (Simanjuntak et al., 2020). The weak control system gives authorized officials the opportunity to commit irregularities (Handayani et al., 2020; Wirawan et al., 2020). Furthermore, Prabowo (2014) states that corruption in Indonesia is the result of a rational decision-making process in which individuals view and analyze their environment to determine in their favor whether or not they commit corruption. Corrupt actors have a subjective assessment of each perceived cost-benefit element. The existence of the fraud triangle encourages corruption actors to become corrupt or not; with rational consideration of cost benefit and the system. Thai (2001) stated that the environment and the public procurement system have an effect on project quality. A strict control and supervision system will further minimize fraud and corruption. Mahmood (2010) also states that the perceived norms of each individual involved in public procurement can lead to forms of fraud, manipulation and corruption. Based on this description, the hypotheses proposed in this study are as follows:

H2a: Individual's low subjective norms have a positive effect on intention to corrupt. 


\subsection{Behavioral Control and Intention for Corruption and Corrupt Behavior}

The fraud triangle theory states that there is rationalization. Rationalization is a view that basically a person can be trusted; even if the person concerned is cheating or corrupt, it does not make him think of himself as a corruptor, so that if he is caught for cheating, they consider that they are victims of a bad system or environment or an environment that considers corrupt acts to be normal (Association of Certified Fraud Examiners, 2013). Prabowo (2014) states that the rationalization factor is the perspective of corruption actors to justify their corruption. The rationalization factor is related to the moral and psychological components, which are very important to understand what causes unethical actions that can lead to corrupt actions (Cohen et al., 2012). In the social psychology literature, Ajzen (1991) emphasizes the role of intentions in explaining behavior; and placing the intention to behave influenced by: attitudes toward the behavior, subjective norms and perceived behavioral control. This is known as the theory of planned behavior (TPB). Moral and psychological aspects are proxied into factors: attitudes toward the behavior, (2) subjective norms and (3) perceived behavioral control (Ajzen, 1991; Cohen et al., 2012). Research on the procurement of goods and services by the Indonesian government was conducted by Sartono (2006) with the findings stating that there are differences in perceptions between the government's internal auditors (Financial and Development Supervisory Agency/BPKP) and the Government Goods and Services Procurement Committee. The findings demonstrate that the actors involved in public procurement have different perceptions of the influence of the income of the goods/services procurement committee, the systems and procedures for the procurement of goods/services, the ethics of the procurement of goods/services, and the environment for the procurement of goods/services on corruptive behavior, except for the quality of the goods/services procurement committee. This is also revealed by previous studies, highlighting the relationship between behavioral control and corruption, including in public procurement (Søreide, 2002; Prabowo \& Cooper, 2016; Park \& Blenkinsopp, 2009). Based on this description, the hypotheses proposed in this study are as follows:

H3a: Lack of behavioral control has a positive effect on intentions for corruption. H3b: Lack of behavioral control has a positive effect on corrupt behavior.

\subsection{The Relationship of Intention to Corruption and the Phenomenon of Corruption}

Among the 3 elements of the fraud triangle, rationalization is an element related to attitude which can be further explained by the theory of planned behavior (Cressey, 1953). In this study, the rationalization factor was developed into 3 factors: attitudes toward the behavior, subjective norms and perceived behavioral control (Cohen et al. 2012). In the theory of planned behavior (Cressey, 1953), it is stated that these three variables will affect an individual's intention to do something, which then the intention is accompanied by pressure and opportunity then cheating can occur. In terms of corrupt attitudes, Kravtsova et al., (2017) stated that from several countries, there was a significant influence on the existence of post materialist value with bribery approval on various multi-level frameworks. Kravtsova et al., (2017) concluded that people who emphasize the existence of hedonism values will justify attitudes, norms, and control over bribery, and sociocultural factors of corruption provide a complex picture of post-materialism (Lambsdorff, \& Teksoz, 2004). This reinforces that the system and environment have an effect on the heightened intention to manipulate, fraud or corrupt the organization (Rabl, 2011; Graf Lambsdorff, 2015). Based on this description, the hypotheses proposed in this study are as follows:

H4: There is a positive relationship between intentions for corruption and corrupt behavior.

\section{Research Methods}

Conceptually, this study adopts the two theories of the fraud triangle (Cressey, 1953) and the theory of the planned behavior (Ajzen, 1991) to study the opportunity and financial process factors and the rationalization factor which emphasizes the moral psychological aspects. This study also explores how the construction of social values that develops which can be tested whether it affects attitudes, subjective norms possessed by society, and their perceived behavior control, with 265 respondents to public accountants, stakeholders, civil servants and inspectors in Central Java. The population of this research is government officials, people's representatives, suppliers of public procurement, accounting lecturers, internal auditors, external auditors, the Financial and Development Supervisory Agency (BPKP), and the community leaders. The number of the population is unknown, so according to Sekaran\& Bougie (2016), this study will use a sample of +330 respondents using a proportional sampling technique. There are four main hypotheses proposed in this study and will be tested using the Structural Equation Model (SEM) analysis technique. The hypothesis is accepted with a level of $\alpha=5 \%$. The results of this study are expected to provide an overview of the attitudes and behavior and value system of corrupt behavior in governance. Corrupt behavior can take the form of gratuities, bribes, and mark-ups for the procurement of government goods and services. By understanding these factors, it is hoped that these factors will be useful in social engineering policies to prevent and detect corrupt behavior. The technique used to analyze the data is Structural Equation Modeling (SEM) with AMOS. 


\section{Results}

\subsection{Validity and Reliability Test}

The test results show that the attitude variable has an accepted validity value for each construct $(\lambda$ AT $1=0.887 ; \lambda$ AT3 $=0.856)$, and the AVE value of 0.760 and CR of 0.752 for the reliability test (Table 1). This shows that the attitude variable has a valid and reliable value. Furthermore, the subjective norm variable has a valid $\lambda$ value for each construct, respectively $\lambda \mathrm{SN} 1$ of 0.833 and $\lambda \mathrm{SN} 2$ of 0.875 . For the reliability test, the results showed an AVE of 0.730 and a CR of 0.745 . This means that subjective norm constructs are declared valid and reliable. For the behavioral control (BC) variable, the test results also show the value of $\lambda$ for the $\mathrm{BC} 1$ construct of 0.876 and $\lambda \mathrm{BC} 2$ of 0.869 , and the AVE value of 0.761 and $\mathrm{CR}$ of 0.753 for the reliability test. This means that all behavioral control constructs are valid and reliable.

Table 1

Validity and Reliability Test

\begin{tabular}{|c|c|c|c|c|c|c|}
\hline Variable & Indicator & $\lambda$ & Validity & AVE & $\mathbf{C R}$ & Reliability \\
\hline \multirow{2}{*}{ Attitude } & AT1 & 0.887 & valid & \multirow[t]{2}{*}{0.760} & \multirow[t]{2}{*}{0.752} & \multirow[t]{2}{*}{ reliable } \\
\hline & AT2 & 0.856 & valid & & & \\
\hline \multirow{2}{*}{$\begin{array}{c}\text { Subjective } \\
\text { Norms }\end{array}$} & SN1 & 0.833 & valid & \multirow[t]{2}{*}{0.730} & \multirow[t]{2}{*}{0.745} & \multirow[t]{2}{*}{ reliable } \\
\hline & SN2 & 0.875 & valid & & & \\
\hline \multirow{2}{*}{$\begin{array}{c}\text { Behavior } \\
\text { Control }\end{array}$} & $\mathrm{BC} 1$ & 0.876 & valid & \multirow[t]{2}{*}{0.761} & \multirow[t]{2}{*}{0.753} & \multirow[t]{2}{*}{ reliable } \\
\hline & $\mathrm{BC} 2$ & 0.869 & valid & & & \\
\hline \multirow{4}{*}{$\begin{array}{l}\text { Intention for } \\
\text { corruption }\end{array}$} & INT1 & 0.754 & valid & \multirow[t]{4}{*}{0.627} & \multirow[t]{4}{*}{0.909} & \multirow[t]{4}{*}{ reliable } \\
\hline & INT 2 & 0.818 & valid & & & \\
\hline & INT 3 & 0.863 & valid & & & \\
\hline & INT 4 & 0.725 & valid & & & \\
\hline \multirow{4}{*}{$\begin{array}{l}\text { Corrupt } \\
\text { Behavior }\end{array}$} & CB1 & 0.541 & valid & \multirow[t]{4}{*}{0.509} & \multirow[t]{4}{*}{0.889} & \multirow[t]{4}{*}{ reliable } \\
\hline & CB2 & 0.706 & valid & & & \\
\hline & CB3 & 0.781 & valid & & & \\
\hline & CB4 & 0.798 & valid & & & \\
\hline
\end{tabular}

The test results for the mediating variable of corruption intention and the dependent variable of corruption behavior show that all constructs are valid and reliable. This is indicated by the $\lambda$ value for the constructs of behavioral intention INT1, INT2, INT3 and INT4 respectively $0.754,0.818,0.863$, and 0.725 , and the AVE and CR values of 0.627 and 0.909 . Furthermore, for the variable of corruption behavior, the values all $\mathrm{CB}$ constructs of $\lambda$ were 0.541 (CB1), 0.706 (CB2), 0.781 (CB3), and 0.798 (CB4), with AVE and CR values of 0.509 and 0.889 . This means that all the constructs of the mediating variables of corruption intention and the dependent variable of corrupt behavior are valid and reliable. This shows that all constructs are valid and reliable, so that the analysis can be continued to the next stage.

\subsection{Goodness-of-Fit Test}

The test results as shown in Table 2 show that all indexes in the Goodness-of-Fit test are accepted and fit. This is characterized

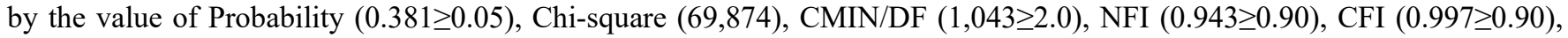
TLI (0.997 $\geq 0.90)$, GFI (0.924 $\geq 0.90)$, AGFI (0.881 $\geq 0.90)$, and RMSEA (0.019 $\geq 0.90)$.

Table 2

Goodness-of-Fit Test

\begin{tabular}{cccc}
\hline Indices & Results & Cut-off value & \multicolumn{2}{c}{ Verification } \\
\hline Prob & 0.381 & $\geq 0.05$ & Fit \\
Chi-square & 69.874 & - & Fit \\
CMIN/DF & 1.043 & $\geq 2.0$ & Fit \\
NFI & 0.943 & $\geq 0.90$ & Fit \\
CFI & 0.997 & $\geq 0.90$ & Fit \\
TLI & 0.997 & $\geq 0.90$ & Fit \\
GFI & 0.924 & $\geq 0.90$ & Fit \\
AGFI & 0.881 & $\geq 0.90$ & Fit \\
RMSEA & 0.019 & $\geq 0.90$ & Fit \\
\hline
\end{tabular}


Furthermore, the Goodness of Fit tests with dependent observations which is tested partially by distinguishing the types of independent variables, and the independent-mediating variable, as shown in Fig. 1 also reveals the fulfillment of the discrepancy between the observed value and the expected value in a fit model (Fig. 1).

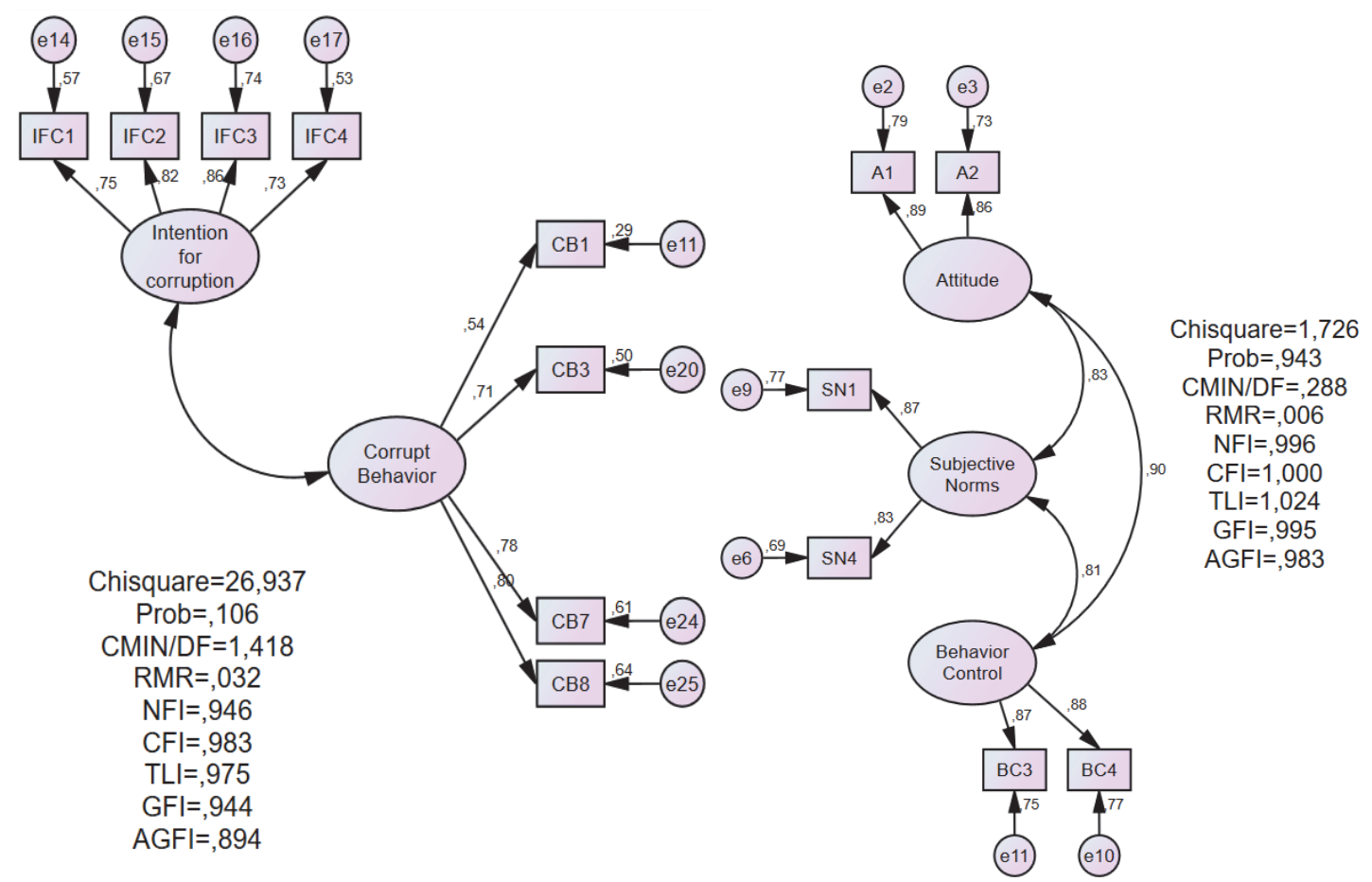

\subsection{Hypothesis testing}

Fig. 1. Goodness of Fit Tests with Dependent Observations

The next test is a hypothesis test to analyze the relationship and the magnitude of the influence or coefficient of the independent variable on the independent variable which is mediated by the mediating variable of corruption intention. The test is accepted by analyzing the magnitude of the coefficient (positive or negative) in accordance with the hypothesis proposed in the framework of this study model (Table 3; Fig. 2).

The first hypothesis states that a low attitude towards corruption is positively related to intention to corruption (H1a), and a low attitude towards corruption is positively related to behavior for corruption (H1b). The test results show that the attitude variable has an Estimate of 0.173, S.E of 0.158, C.R of 1.094, and a p-value of 0.27. This test result confirms the positive direction (sign) of the coefficient. This means that there is a positive relationship between low attitudes towards corruption and a positive relationship with intention to corruption. This means H1a is accepted.

The $\mathrm{H} 1 \mathrm{~b}$ test confirms the magnitude of the influence of attitude on behavior for corruption. The statistical results show that the attitude in its influence with corrupt behavior has an Estimate of -0.032, S.E of 0.123, C.R of -0.264, and a p-value of 0.792. This result shows a sign of negative coefficient. This shows that $\mathrm{H} 1 \mathrm{~b}$ which states that a low attitude towards corruption is positively related to behavior for corruption is rejected. This indicates that a low attitude towards corruption only has a positive effect on intention, and does not directly justify corrupt behavior.

Furthermore, statistical tests confirm the findings on hypothesis testing regarding the effect of subjective norms on intention for corruption and corrupt behavior. In this context, statistical testing on the influence of low behavior control on intention to corruption (H2a) shows an Estimate of 0.154, S.E of 0.102, C.R of 1.519 and a p-value of 0.129. The coefficient value shows a positive direction. This suggests that the lack of a subjective norm in viewing corruption positively affects the intentions for corruption. This indicates that $\mathrm{H} 2 \mathrm{a}$ is acceptable. Further tests regarding the influence of subject matter norms on corrupt behavior revealed a positive influence, as indicated by Estimate of, 509, S.E of, 125, C.R of 4.086 and p-value of $0.000(<0.05)$. This means that the lack of subjective norms has a positive and significant effect on corrupt behavior. These results confirm that $\mathrm{H} 2 \mathrm{~b}$ is accepted. 
Table 3

Hypothesis Test Results

\begin{tabular}{llllllll} 
& & & Estimate & S.E. & C.R. & P & Label \\
\hline Intentions & $\leftarrow$ & Attitude & .173 & .158 & 1.094 & .274 & par_1 \\
Intentions & $\leftarrow$ & Subjective Norms & .154 & .102 & 1.519 & .129 & par_2 \\
Intentions & $\leftarrow$ & Control & .369 & .166 & 2.230 & .026 & par_3 \\
Behavior & $\leftarrow$ & Intentions & .266 & .163 & 1.637 & .102 & par_4 \\
Behavior & $\leftarrow$ & Attitude & -.032 & .123 & -.264 & .792 & par_17 \\
Behavior & $\leftarrow$ & Norms & .509 & .125 & 4.086 & .000 & par_18 \\
Behavior & $\leftarrow$ & Control & -.072 & .141 & -.512 & .608 & par_19 \\
\hline
\end{tabular}

The third hypothesis test confirms that the lack of control behavior has a positive effect on the intention to corrupt (H3a) and on corrupt behavior $(\mathrm{H} 3 \mathrm{~b})$. The test results show that the Estimate value for the effect of behavioral control on intention to corruption is 0.369 , S.E of 0.166 , C.R of 2.230 , and p-value of, 026 . This indicates that the lack of behavioral control has a positive effect on intention to corruption, which is indicated by a positive Estimate value, and a significance value $<0.05$ in the 95\% confidence level. This means, H3a which states that the lack of behavioral control has a positive effect on the intention to corrupt is accepted. Furthermore, statistical testing on the effect of lack of behavioral control on behavior on corrupt behavior shows the Estimate value of -0.072 , S.E of 0.141 , C.R of -0.512 and p-value of 0.608 . These results indicate a negative Estimate value. This shows that the hypothesis $\mathrm{H} 3 \mathrm{~b}$ is rejected. This provides empirical evidence that a lack of behavioral control only positively affects intentions for corruption, but not on corrupt behavior. Furthermore, the test is conducted to empirically analyze the influence of the mediating variable of intention for corruption on corrupt behavior. The test results show that the intention for corruption has an Estimate of 0.266, S.E of 0.163, C.R of 1.637 and a p-value of 0.102. This shows that the intention to corrupt has a positive influence on corrupt behavior. This means that the fourth hypothesis which states that the influence of intention to corruption on corrupt behavior is accepted.

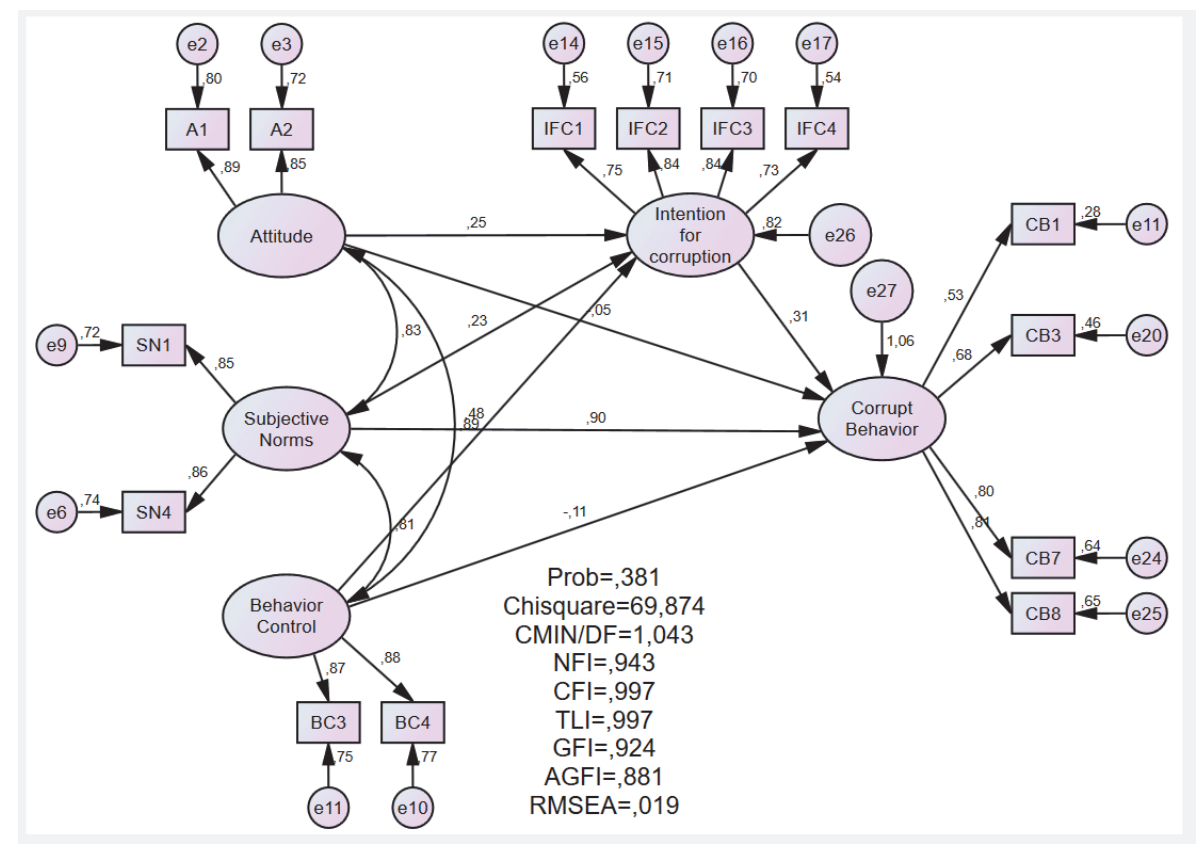

Fig. 2. Full Model

The results confirmed the findings stating the importance of psychological outlook of individuals in attaining the visible behavior in accounting practices (Birnberg et al., 2006; Covaleski et al., 2003; Hall, 2010). More importantly, the findings also need to be considered important as a theoretical perspective for combining management accounting research from a psychological perspective as stated by Birnberg et al. (2006). Also, the results denote the interests of fraud triangle theory (Dellaportas, 2013), and the theory of planned behavior (TPB) in public sector accounting (Brown et al., 2016; Latan et al., 2019), especially to minimize corruption intention and behavior, fraud and manipulation (Barr-Pulliam, 2017; Gottschalk, 2019). The theories in this context present that actual behavior is a derivation of psychological drives and is subjective for each individual. This is also 
supported the previous literature examining the importance of social constructs in corruption practices in public sector (Zulaikha et al., 2019; Ulum et al., 2019). Managerially, the findings underline the need for tiered supervision in the implementation of goods and services procurement projects in the public sector, improve the quality of reporting and accounting systems, and enhance individual integrity to carry out work with integrity as demonstrated in previous findings (Zulaikha et al., 2016; Fakhimuddin, 2018; Said et al., 2017).

\section{Conclusion}

The findings indicate that attitudes, subjective norms, and control behavior in direct testing have a positive effect on intention to corruption. In addition, the empirical results also show that the low level of subjective norms also has a direct positive effect on corrupt behavior. This shows that the intention of corruption is supported by low attitudes, subjective norms and a lack of control over behavior that allows someone to have corrupt intentions. However, further testing also shows that the positive influence of attitude and behavior control on this intention to corruption does not justify corrupt behavior. This is proven empirically by the negative and insignificant value of the influence of attitudes and behavior control on corrupt behavior. This is possible because corrupt behavior is not only supported by the existence of attitudes, subjective norms and individual behavioral control, but also by considering the external environment in the form of supervision and control inherent in the workplace which may make it less possible for an individual to commit corruption. Furthermore, the statistical results show that the intention to corrupt has an influence on corrupt behavior. This is indicated by the positive influence of the variable of intention for corruption on corrupt behavior. This makes corrupt behavior in the context of the procurement of goods and services in Indonesia possible if an individual already has the intention, and is supported by external conditions and a supportive environment, such as low supervision and supervision in the procurement of goods and services. These results theoretically indicate that subjective elements need to be considered important in analyzing the psychology of corruption. Attitude elements, subjective norms and behavior control are subjective psychological conditions for each individual, but have an influence on intention and behavior. These results support the theory of planned behavior (TPB), which proposes that actual behavior is a derivation of psychological drives and is subjective for each individual. Furthermore, in practical terms, these findings underline the need for tiered supervision in the implementation of goods and services procurement projects in the public sector, improve the quality of reporting and accounting systems, and enhance individual integrity to carry out work with integrity. In addition, this study confirms the need for training to improve individual skills, especially auditors to analyze crucial aspects of corruption in the procurement of goods and services. Bureaucratically, these findings are important to encourage increased remuneration for employees and competitive pricing for the private sector involved in procurement projects to minimize intentions for corruption and corrupt behavior by improving the quality of life of individuals involved in supervision, auditing and reporting.

\section{References}

Ajzen, I. (1991). The theory of planned behavior. Organizational behavior and human decision processes, 50(2), $179-211$.

Association of Certified Fraud Examiners/ACFE. (2013). Report to Members Past Successes, Future Goals: 2013 Year in Review. Retrieved from https://www.acfe.com/report-to-members-2012.aspx

Ateljevic, J., \& Budak, J. (2010). Corruption and public procurement: example from Croatia. Journal of Balkan and Near Eastern Studies, 12(4), 375-397.

Barr-Pulliam, D. (2017). The relationship between internal audit assurance frequency and earnings manipulation intent and behavior: A theory of planned behavior approach. Available at SSRN 3093735.

Birnberg, J. G., Luft, J., \& Shields, M. D. (2006). Psychology theory in management accounting research. Handbooks of Management Accounting Research, 1, 113-135.

Brown, J. O., Hays, J., \& Stuebs Jr, M. T. (2016). Modeling accountant whistleblowing intentions: Applying the theory of planned behavior and the fraud triangle. Accounting and the Public Interest, 16(1), 28-56.

Cohen, J., Ding, Y., Lesage, C., \& Stolowy, H. (2012). Corporate fraud and managers' behavior: Evidence from the press. In Entrepreneurship, governance and ethics (pp. 271-315). Springer, Dordrecht.

Covaleski, M. A., Evans III, J. H., Luft, J. L., \& Shields, M. D. (2003). Budgeting research: three theoretical perspectives and criteria for selective integration. Journal of Management accounting research, 15(1), 3-49.

Cressey, D. R. (1953). Other people's money; a study of the social psychology of embezzlement.

Dellaportas, S. (2013). Conversations with inmate accountants: Motivation, opportunity and the fraud triangle. Accounting Fórum, 37(1), 29-39.

Dorminey, J., Fleming, A. S., Kranacher, M. J., \& Riley Jr, R. A. (2012). The evolution of fraud theory. Issues in accounting education, 27(2), 555

Fakhimuddin, M. (2018). Reconsidering Accounting Information Systems: Effective Formulations for Company's Internal Control. Arthatama Journal of Business Management and Accounting, 2(1).

Financial and Development Supervisory Agency/BPKP. (1999). Strategi Pemberantasan Korupsi Nasional. Jakarta: Financial and Development Supervisory Agency/BPKP

Gottschalk, P. (2019). Fraud and corruption: A convenience perspective. Universal-Publishers. 
Graf Lambsdorff, J. (2015). Preventing corruption by promoting trust: insights from behavioral science (Vol. 69, No. 15). Passauer Diskussionspapiere-Volkswirtschaftliche Reihe.

Hall, M. (2010). Accounting information and managerial work. Accounting, Organizations and Society, $35(3), 301-315$.

Handayani, B.D., Rohman, A., Chariri, A., \& Pamungkas, I.D. (2020). The dynamics of the political environment in the disclosure of local government financial statements: An insight from Indonesia. International Journal of Innovation, Creativity and Change 11(8), pp. 94-109.

Hehamahua, A. (2011). Procurement of Goods and Services, Corruption, and Bureaucratic Reform. Retrieved March 13,2012 from http://www.lkpp.go.id.

Kravtsova, M., Oshchepkov, A., \& Welzel, C. (2017). Values and corruption: Do postmaterialists justify bribery?. Journal of Cross-Cultural Psychology, 48(2), 225-242.

Lambsdorff, J. G. (1999). November. Corruption in empirical research: A review. Transparency International Working Paper, $1-17$.

Lambsdorff, J. G., \& Teksoz, S. U. (2004). Corrupt relational contracting. In The new institutional economics of corruption (pp. 152-165). Routledge.

Latan, H., Jabbour, C. J. C., \& de Sousa Jabbour, A. B. L. (2019). 'Whistleblowing Triangle': Framework and Empirical Evidence. Journal of Business Ethics, 160(1), 189-204.

Mahmood, S. A. I. (2010). Public procurement and corruption in Bangladesh confronting the challenges and opportunities. Journal of Public Administration and Policy Research, 2(6), 103-111.

Park, H., \& Blenkinsopp, J. (2009). Whistleblowing as planned behavior-A survey of South Korean police officers. Journal of Business Ethics, 85(4), 545-556.

Prabowo, H. Y. (2014). To be corrupt or not to be corrupt. Journal of Money Laundering Control.

Prabowo, H. Y., \& Cooper, K. (2016). Re-understanding corruption in the Indonesian public sector through three behavioral lenses. Journal of Financial Crime, 23(4), 1028-1062

Rabl, T. (2011). The impact of situational influences on corruption in organizations. Journal of Business Ethics, $100(1)$, 85-101.

Said, J., Alam, M., Ramli, M., \& Rafidi, M. (2017). Integrating ethical values into fraud triangle theory in assessing employee fraud: Evidence from the Malaysian banking industry. Journal of International Studies, 10(2).

Sartono. (2006). Analisis Faktor-Faktor yang Mempengaruhi Terjadinya Penyimpangan dalam Pengadaan Barang/Jasa di Lingkungan Instansi Pemerintah. (Unpublished Thesis, Faculty of Economics, University of Indonesia).

Sekaran, U., \& Bougie, R. (2016). Research methods for business: A skill building approach. John Wiley \& Sons.

Simanjuntak, D., Utama, Y.J., Saraswati, R., Sukirno, \& Sinaga, R.Y. (2020). Reconstruction of village funds supervision: An action to prevent corruption in village funds management. Test Engineering and Management 83, 11850-11863

Søreide, T. (2002). Corruption in public procurement. Causes, consequences and cures. Chr. Michelsen Intitute.

Telgen, J., Harland, C., \& Knight, L. (2012). Public procurement in perspective. In Public procurement (pp. 44-52). Routledge.

Thai, K. V. (2001). Public procurement re-examined. Journal of Public Procurement, 1(1), 9-50.

Transparency International Indonesia/TII (2019). Corruption Perceptions Index 2019. Retrieved from https://riset.ti.or.id/corruption-perceptions-index-2019/.

Ulum, A.S., Rohman, A., Harto, P., Ratmono, D., \& Ghozali, I. (2019). The role of natural resources on moderating the relationship between fiscal decentralization and corruption: Evidence from Indonesia. International Journal of Energy Economics and Policy 9(1), pp. 67-75.

Umar, H. (2011). National Vigilance Against the Danger of the Spread and Widespread of Corruption Crime. Paper presented at panel discussion, Palembang, 7 April 2011.

Van Rijckeghem, C., \& Weder, B. (1997). Bureaucratic Corruption and the Role of Temptation: Do Low Wages in the Civil Service Cause Corruption. IMF Working Paper Wp/97/73. Washington, DC: International Monetary Fund, Research Department.

Wirawan, A., Saraswati, R., Sa'adah, N., \& Sinaga, E.N. (2020). Preventing corporate corruption through strengthening accounting education in higher education. Test Engineering and Management 83, 11767-11779

Zulaikha, Basuki Hadiprajitno, P.T., \& Amal, M.I. (2019). Social constructs in predicting corruptive attitudes and behavior from theory of planned behavior perspective. International Journal of Economics and Business Administration 7(3), 167-177

Zulaikha, Ghozali, I., \& Hadiprajitno, P.T. (2016). Factors affecting the government procurement fraud: The independent auditor's point of view evidence from Indonesia. Corporate Board: Role, Duties and Composition 12(3), 61-68.

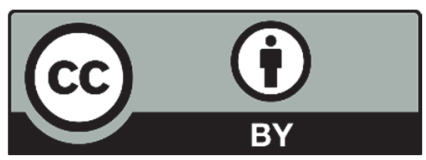

(C) 2021 by the authors; licensee Growing Science, Canada. This is an open access article distributed under the terms and conditions of the Creative Commons Attribution (CC-BY) license (http://creativecommons.org/licenses/by/4.0/). 